\title{
“소녀들의 보다 나은 삶”의 포괄적 연구와 한국의 글로벌 리더십1)
}

제 I 장

개
발
협
력
이
슈

제 II 장

제 III 장

제 $\mathbb{N}$ 장

I. 서론

II. 개발도상국 당시 한국의 공중보건사업 분석: 여성과 영아 건강을 중심으로

III. 한국의 글로벌 보건협력 전수 분석

IV. 세계 글로벌 보건협력의 사각지대 분석

V. 에티오피아의 Youth Friendly Service for Sexual and Reproductive Health 사례연구

VI. 개발도상국의 포괄적 소녀건강과 교육에 있어서 한국의 글로벌 리더십

1. 여성건강의 중요성

2. 소녀건강의 중요성

3. 소녀교육의 중요성

1) 본 연구는 2013년부터 빌 앤 멜린다 게이츠재단(Bill \& Melinda Gates Foundation)의 지원을 받아 수행하고 있는 "국제 보건의료 및 개발협력을 위한 한국의 역할 확대 방안 연구(Advocacy for Korean Engagement in Global Health \& Development)”의 일환이다. 본 연구를 위해 이화여자대학교 국제개발협력연구원 및 글로벌소녀건강연구원의 조희정 박사 와 이지은, 정은미, 정다혜 등 연구원들이 다수 참여하였다.

2) 이화여자대학교 국제대학원 원장, 교수/국제개발협력연구원/글로벌소녀건강연구원 원장 (emkim@ewha.ac.kr)

3) 이하 공동저자. 소속은 다음과 같음: 강민아(이화여자대학교 행정학과), 강지현(이화여자대학교 국제학부), 김경효(이화여 자대학교 의학전문대학원), 김승철(이화여자대학교 의학전문대학원), 김영주(이화여자대학교 의학전문대학원), 김은실(이화 여자대학교 여성학과), 김의정(이화여자대학교 의학전문대학원), 김현수(이화여자대학교 사회학과), 김혜순(이화여자대학교 의학전문대학원), 박미혜(이화여자대학교 의학전문대학원), 박은애(이화여자대학교 의학전문대학원), 서동철(이화여자대학교 융합보건학과), 유경하(이화여자대학교 의학전문대학원), 이사라(이화여자대학교 의학전문대학원), 이순남(이화여자대학교 의학전문대학원), 정구영(이화여자대학교 의학전문대학원), 정혜원(이화여자대학교 의학전문대학원), 하은희(이화여자대학교 의학전문대학원), 한재진(이화여자대학교 의학전문대학원). 


\section{초록(Abstract)}

세계에서 유례가 드물게, 원조를 받던 수원국에서 빠르게 공여국으로 변모한 한국은 이 제 전 세계의 개발도상국들에게 공적개발원조를 주는 국가가 되었다. 특히 최빈국이었던 한국의 급속한 빈곤 퇴치, 경제 발전, 민주화 등의 경험은 개발도상국들에게 희망이 되고 있다.

본 연구는 새로운 공여국으로서 남다른 역사를 지닌 한국이 어떻게 하면 세계 보건협 력 분야에서 조금 더 의미 있는 기여를 할 수 있는가에 대한 연구로, 2013년부터 Bill \& Melinda Gates Foundation의 연구비 지원을 받아 진행하였다. 개발협력 전문가, 공중 보건 전문가, 의학 전문가들이 다학제적 연구팀을 구성, 2 년여 동안 4 단계의 연구를 진행 하였다. 첫 단계로 한국의 개발도상국 당시의 성공적 공중보건사업에 대한 연구를 여성과 영아 건강을 중심으로 살펴보았다. 두 번째 단계로, 한국이 원조공여국으로서 20082012년에 국제보건협력분야에서 KOICA, KOFIH, EDCF를 통해 지원한 사업에 대한 전 수 분석을 하였고 이를 통해 한국의 기여가 아직은 규모면에서 적을 뿐만 아니라 어떤 특 성을 나타내지 않고 있다는 결론을 내렸다. 세 번째 단계 연구로 세계의 국제보건협력에 서 사각지대에 있는 분야가 영유아와 모성건강이라는 것을 확인하고 그 원인에 대한 고찰 을 하였다. 이의 주요 원인으로 국제모자보건사업의 대상이 18 세 이상 가임여성인데, 실 제로 개발도상국에서는 18 세 미만, 특히 15 세 미만 소녀의 임신과 출산이 문제로 대두된 바, 소녀들을 대상으로 국제보건협력이 이루어져야 할 것을 제안했다. 네 번째 단계 연구 는 에티오피아의 KOICA 보건협력 사례를 통해 향후 소녀건강과 교육관련 국제개발협력 사업에 대한 시사점을 얻고자 질적 연구를 진행하였다.

본 연구 결과, '포괄적 소녀 건강과 교육'이 세계보건 개발협력 분야의 사각지대에 있음 을 밝히고 이 연구결과를 한국 정부에 제안하였고, 한국 정부가 '소녀들의 보다 나은 삶 (Better Life for Girls)' 구상을 2015년 UN 개발정상회담에서 발표하게 되었다.

주제어: 소녀들의 보다 나은 삶, 국제보건의료, 글로벌 리더십 


\section{I. 서론}

한국 정부는 1987년 유상원조 기관 설립, 1991 년 무상원조 기관 설립, 1995 년 원조대상국 명 단 졸업, 2010년 OECD 개발원조위원회(Development Assistance Committee, DAC) 가입, 2011년 부산세계개발원조총회 개최, 2015년 UN 개발정상회의에서 'Better Life for Girls' 이니 셔티브 발표로 이어지는 원조공여국으로서 숨가쁜 발전을 거듭해오고 있다. 한국은 1945년 미국 으로부터 제 2 차 세계대전 후 전쟁 발발 국가의 구 식민지에 대한 원조를 받으면서 1995년까지 127.8 억 불의 원조를 통해 빈곤 퇴치와 경제 발전을 이룩하고 민주화를 일구어낸, 전 세계에서 보기 드문 원조 수원국에서 공여국으로의 변환 역사를 가지고 있는 국가이다.

제 I 장

개

발

협

력

이

슈

제 II 장

제 III 장

제 IV장 협력 분야에서 조금 더 의미있는 기여를 할 수 있는가에 대한 연구로, 2013년부터 Bill \& Melinda Gates Foundation의 연구비 지원을 받아 진행하였다. 개발협력 전문가, 공중보건 전문가, 의학 전문가들이 다학제적 연구팀을 구성, 2 년여 동안 연구한 결과, '포괄적 소녀 건강과 교육'이 세계 보건 개발협력 분야의 사각지대에 있음을 밝히고 이 연구결과를 한국 정부에 제안하였고, 한국 정부가 'Better Life for Girls' 구상을 2015년 UN 개발정상회담에서 발표하게 되었다. 본 연구 는 현재 진행 중인 연구로서, 포괄적 소녀 건강과 교육을 제안하게 된 연구 경과를 소개하고, 한 국이 개발도상국의 소녀 건강과 교육에 대해 어떻게 세계적 리더십을 가지고 기여할 수 있는가에 대한 제언을 하고자 한다.

본 연구는 4단계의 연구로 진행하였다. 첫 단계 연구는, 과거 한국이 개발도상국이었을 당시 어떠한 공중보건 문제가 있었고 이를 해결한 방법, 특히 21세기 개발도상국의 공중보건 문제와 관련하여 검토했을 때 유의미한 경험을 중심으로 살펴보았다. 특히, 세계적으로 아직도 사각지대에 놓여있는 여성과 영아 건강을 중심으로 보았다. 두 번째 작업으로는 그동안 한국이 공여국으로서 어떠한 글로벌 보건협력을 해왔는지를 이 분야 사업들을 주로 집행한 한국국제협력단(Korea International Cooperation Agency, 이하 KOICA), 한국국제보건의료재단(Korea Foundation for International Healthcare, 이하 KOFIH), 대외경제협력기금(Economic Development Cooperation Fund, 이하 EDCF)의 2008-2012년의 사업들을 전수 분석하여 그 동안 한국의 무 상원조의 3 대 분야 중 하나인 보건협력 분야에서 어떠한 패턴을 보이고 있는지를 분석하였다. 한 국은 원조 수원국의 수요에 맞추어 지역별, 국가별로 차별화된 전략을 가지고 보건협력사업을 펼 쳤던 것으로 보이나, 한국만의 특별한 전략보다는 세계의 흐름에 부합하는 보건개발협력을 한 것 으로 파악되었다. 세 번째 연구단계에서는 글로벌 보건협력 분야에서 사각지대로 남아 있는 중요 
분야가 무엇인가 하는 것으로서 2001-2015년 시행되었던 전 세계의 글로벌 빈곤퇴치와 사회발전 에 대한 비전을 담아 실행했던 새천년개발목표(Millennium Development Goals, 이하 MDGs) 를 중심으로 세계 보건협력 분야의 성과와 미해결로 남아 있는 도전 과제를 살펴보았다. 네 번째 연구는 위의 3 단계 연구 이후, 포괄적 소녀 건강과 교육이 글로벌 보건협력분야에서 중요한 사각 지대로 남아있음을 밝힌 후에, 향후 개발도상국의 포괄적 소녀건강과 교육을 공적개발원조 (Official Development Assistance, 이하 ODA) 사업으로 발전시키기 위한 선행연구로서 에티 오피아에서 진행 중인 $\mathrm{KOICA}$ 의 보건협력사업 현장에 대한 질적 연구이다.

본 논문에서는 위의 4 단계 연구 결과를 각 장에서 간단히 살펴보고, 포괄적 소녀건강과 교육의 구상을 소개한 후, 한국이 이 분야에서 어떠한 세계적 공감대를 형성하면서 리더십을 발휘하고 기여할 수 있을 것인가에 대한 제언으로 마무리하고자 한다.

\section{II. 개발도상국 당시 한국의 공중보건사업 분석: 여성과 영아 건강을 중심으로}

본 장에서는 한국이 개발도상국 당시의 공중보건사업 경험을 분석하여 21 세기 개발도상국의 공중보건 문제의 맥락에서 의미있는 경험적 사례가 있는지를 찾아보고자 연구를 진행하였다. 본 연구는 1945 년 이후 공중보건 사업을 중심으로, 특히 여성과 영아 건강에 초점을 맞추어 살펴보 았다.

한국의 공중보건사업의 발달과정을 여러 방식으로 나누어 볼 수 있겠으나, 본 연구에서는 방숙 (2012)의 5단계를 중심으로 살펴보고자 한다: (1) 1945-1960년: 보건 시스템 형성과 전염병 예 방·방역, (2) 1960-1969년: 보건 네트워크 구축과 가족계획사업 확산, (3) 1971-1980년: 지역 보건사업 구축 초기, (4) 1980-1989년: 의료보험 등 복지 정책 강화, (5) 1990-1999년: 보건 소 및 지역보건사업 확산기로 대별할 수 있다.

특히 한국은 1945-1948년 미군정 당시 미국 의료 제도의 영항을 받아 공적의료기구는 치료보 다는 예방보건에 전념하는 의료체제를 갖게 되었다. 공중보건은 보건소를 중심으로 전개되었고, 한국전쟁 이후에는 전염병 등을 예방하는 방역행정이 주축을 이루었다(문옥륜, 2015: 18-19).

1946년 한국에 최초의 모범보건소 설립, 1956 년 보건소법 제정, 1995 년 지역보건법으로의 개 정 등의 과정을 거치면서 한국의 공중보건의 역사는 보건소를 중심으로 하는 지역보건사업으로 
전개되어왔다(KDI 국제정책대학원, 2011). 보건소 및 보건지소는 주로 공중보건의에 의해 운영 되며 가족계획, 예방접종, 결핵 관리, 식품 검열, 위생사업, 보건통계의 수집, 모자보건사업의 수 행 등을 위주로 하였다. 1960 년경부터 농촌지역의 보건소 설치 및 역할 강화, 서비스 수준의 향 상, 인력 역량 강화 등이 영아사망률 감소와 같은 성과에 긍정적인 기여를 한 것으로 보였다. 특 히 1978년 국민보건의료를 위한 특별조치법 및 1980년 농어촌 등 보건의료를 위한 특별조치법 제정으로 지역보건소의 역량 및 사업의 질적 수준이 강화되었고, 이로 인해 산모와 영유아의 보 건소 방문 및 예방 접종 서비스의 활용 등 긍정적인 성과를 도출하게 된 것으로 보인다 $\mathrm{KDI}$ 국제 정책대학원, 2011).

특히 무의지역 해소를 위한 대책으로 개업의를 위촉하는 방안, 특정의무 지정 의사제도 도입, 공중보건 장학의사 제도 등이 시도되었으며, 예비역 병적에 편입된 자를 3 년간 무의지역에 근무 하게 하여 병역의무를 면제하도록 하는 제도가 1979년부터 시행되었다.

제 I 장

개

한편, 이러한 일련의 발전에 대해 국제적 영향력 또한 작용한 것으로 보인다. 예를 들어, 1980 년 농어촌 등 보건의료를 위한 특별조치법의 제정에 있어서는 1978년 WHO-UNICEF의 알마알타 선언에 대한 한국 정부의 공식적인 대응이었으며, 기타 건강보험제도의 확산 등을 포함한 일련의 정책적 변화는 국제사회의 요구에 대한 부응으로 해석되기도 한다(박형종·김공현, 1991).

특히 한국의 경제발전 초기인 1960년대에 인구증가율을 감소시키고 이로 인해 국민소득의 증 가를 가져오기 위해 강력한 가족계획사업이 시행되었다. 이 과정에서 모성 사망률과 영아 사망률 감소가 중요한 목표로 인식되어 가족계획사업과 함께 결합되어 실행되었다. 특히 이 과정에서 지 방의 조직행정력이 중요한 기여를 했고, 여성들 스스로 자녀 수 제한에 동의하도록 하는데 영아 및 모성 사망 방지를 위한 의료 서비스의 확산이 주효했다고 본다(방숙, 1986 ; 김은실, 2001). 그 결과, 1960 년대 한국의 합계출산율은 6.0 명이었고, 가족계획사업의 성공적 실시 후 1980 년대 에 출산율이 2.83 명이 되었다(통계청, 각년도).

한국은 한국전쟁이 끝날 무렵 매우 높은 영아사망률을 기록하였다. 1960년 대만은 1,000명 당 54 명이었으나 한국은 90 명이었다. 이후 급속한 경제성장과 사회발전을 이루면서 영아사망률이 감 소하고 기대수명 또한 급속하게 증가하였다. 전쟁 이후 약 45 년간의 기간 동안 영아사망률의 감 소 추세는 2005 년의 경우 145 개의 국가 중 3 번째로 영아사망률의 감소가, 그리고 170 개 국가 중에서 6번째의 기대수명 증가를 기록했다(McGuire, 2010). 비율로 볼 때 1960년을 기준으로 1970 년대에 가장 급속한 속도로 감소하였고 1980년대와 1990년대에도 그 추세가 이어졌다 (OECD, 2005).

한국과 중남미, 대만, 인도네시아 등을 포함한 7 개 국가에서의 보건의료 개선 정책 및 효과를 
고찰한 맥과이어(McGuire, 2010)는, 한국의 공공보건분야 발전 및 영아사망률의 효과적인 감소 에 대한 다양한 요인들을 파악하기 위해 한국전쟁 이후 실행된 다양한 사업을 고찰하고, 시대적 으로는 1950년대에는 공공교육의 장려, 1960 년대까지는 가족계획 사업, 1970 년 초반 식수위생 사업, 그리고 1970 년대 후반부터의 모자보건 사업 노력이 핵심적인 사업으로 수행된 것으로 구분 하였다. 그는 한국의 경제적 발전뿐만 아니라 사회·교육정책의 발전, 그리고 공공보건 분야 프로 그램에서의 적극적인 노력으로 단기간 내 영아사망률의 감소라는 성과가 가능했던 것으로 분석하 였다(McGuire, 2010). 특히 한국에서의 영아사망률 감소는 경제발전이나 정부의 보건의료 예산 증가, 건강보험제도의 확산 및 정착과 같은 요인보다는 지역을 중심으로 한 위생식수 사업과 같 은 기본적 사회 서비스와 모자보건 서비스 및 영양 사업 등이 중요한 역할을 한 것으로 분석하였 다(McGuire, 2010).

개발도상국의 영아사망률의 감소는 모성의 교육수준이 가장 중요한 영향요인으로 보고되는데, 한국의 경우도 예외가 아니었다. 해방 이후 교육에 대한 집중적인 관심과 투자가 이루어져서, 1949년 초등교육 의무화가 실시되었고, 그 후 학교 등록률 및 이수율이 급격히 증가하였다. 특히 여학생들의 등록률이 급속히 증가하여 남녀 격차를 빠르게 줄이고 향후 출산률 및 영아 사망률 저하에 기여했다고 하겠다. 이러한 한국의 경험은 21 세기 개발도상국들이 모성과 영유아 사망률 을 줄이기 위한 여러 노력에 중요한 시사점을 주고 있다.

이 외에도 한국이 개발도상국 당시 공중보건사업을 다분야에서 다각적으로 시행하면서 한국의 경제 및 사회발전의 중요한 밑거름이 되었다. 본 장에서는 주로 여성과 아동 건강에 관계된 사업 들을 중심으로 살펴보았고, 특히 보건소 중심의 지역보건의료와 교육이 결합되어 여성과 아동 건 강에 성과가 있었다는 것은 21 세기 개발도상국에도 중요한 시사점을 준다.

\section{III. 한국의 글로벌 보건협력 전수 분석4)}

한국은 지난 10 여 년간에 걸친 보건의료 분야 해외지원 사업 경험을 축적해왔으나 이에 대한 전수분석이 아직 없는 현황에서 한국의 글로벌 보건협력 사업이 어떠한 특징과 패턴을 갖고 있는 지를 살펴보기 위해, 국제보건의료 협력사업의 대부분을 집행한 $\mathrm{KOICA}, \mathrm{KOFIH}$ 및 $\mathrm{EDCF}$ 의 사 업의 전수 분석을 실시하였다. 한국 정부는 국제개발협력기본법 등에 근거하여 수원국 중심의 원 조를 하고 있는 바, 본 분석을 통해서 한국의 $\mathrm{ODA}$ 중 보건협력 사업이 집행된 주요 지역, 국가

4) 김은미, 안명옥, 오충현, 강민아, 하은희, 신현상(2014)의 연구 결과를 바탕으로 구성함. 
및 주요 사업패턴을 규명해 보고자 하였다. 분석 대상 및 연구 방법은 아래와 같다.

O 분석 기관: $\mathrm{KOICA}, \mathrm{KOFIH}, \mathrm{EDCF}$

은벅 사업: 위 3 기관의 241개의 보건의료 ODA 사업 (2008-2012)

- KOICA: 198개 (출처: stat.koica.go.kr)

- KOFIH: 13 개 (출처: 창립5주년 백서)

- EDCF: 30개 (출처: edcfkorea.go.kr)

분석 방법

- 보건의료 $\mathrm{ODA}$ 사업 전체 분석

- 사업 분포 (사업 수와 사업 규모) 분석

- 지역별, 주제별, 지역-주제별 분석

2008년부터 2012년까지 한국정부의 국제보건 의료 관련 ODA활동을 분석하였다 (〈표 1〉참 조). 총 프로젝트 수는 241개에 달하였고, 7개 분야에 집중해 있었다(EDCF 2014; KOFIH 2011; KOICA 2014).

〈표 1〉한국 정부의 국제보건의료 ODA 사업, 2008-2012

\begin{tabular}{l|l}
\hline \multicolumn{1}{c|}{ 분야 } & \multicolumn{1}{c}{ 내용 } \\
\hline 보건의료 서비스 접근성 & 주요한 보건의료 프로그램과 보건의료 전달 시스템 강화 \\
\hline 보건의료 인력 자원 & 의료 전문가와 기초 보건인력 교육 \\
\hline 보건의료 시스템 & 보건의료 정보시스템과 보건 정책의 향상 \\
\hline 보건의료 교육 & \\
\hline 모자보건 & 모자보건, 여성 건강, 생식 보건 (Reproductive Health), 가족계획 \\
\hline 감염질병 & HIV/AIDS, 말라리아, 결핵 \\
\hline WASH & 물(Water), 위생(Sanitation) 및 청결(Hygiene) \\
\hline 영양 & \\
\hline 기생충 & * 주혈흡충증 포함 \\
\hline 그 외 & 청소년 보건, 눈 건강, 구강 건강 외. \\
\hline
\end{tabular}

출처: 김은미, 안명옥, 오충현, 강민아, 하은희, 신현상 (2014)

한국의 국제보건의료 ODA 활동 프로젝트는 〈그림 1〉에 잘 나타나 있다. 한국은 보건의료 서비스 분야 ODA 활동에 집중하여 왔고, 다음으로 물, 위생, 청결 문제를 다루는 Water, Sanitation and Hygiene (WASH) 분야에 치중했으며, 세 번째로는 모자 보건(Maternal and Child Health; $\mathrm{MCH}$ ) 분야에 집중하여 왔다. 
〈그림 1〉분야별 국제보건의료 ODA 프로젝트 수

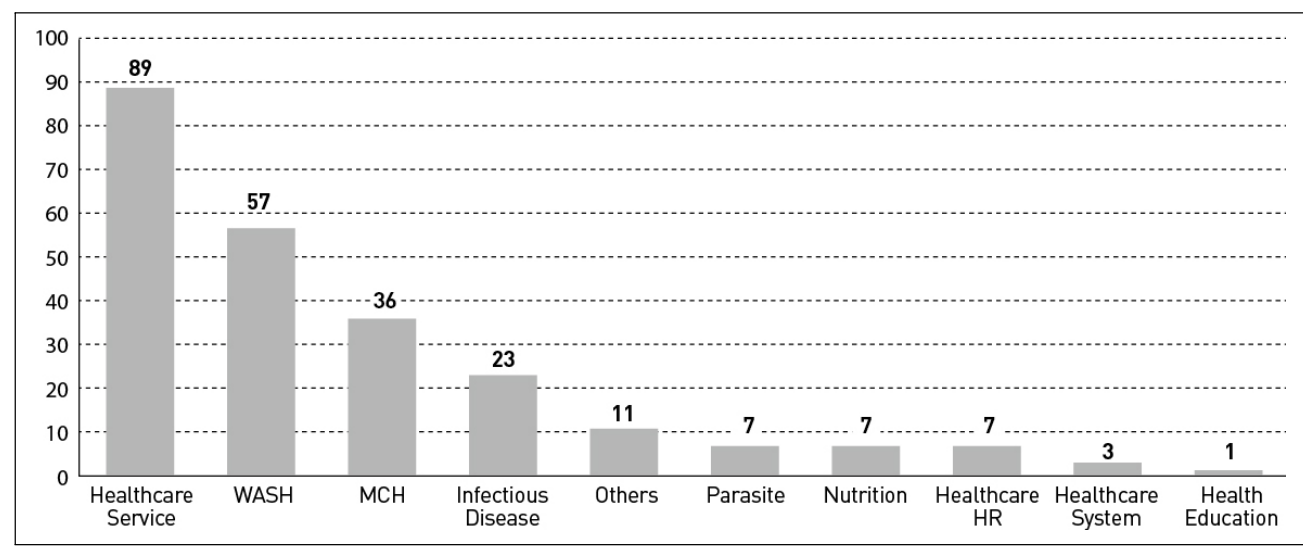

출처: 김은미, 안명옥, 오충현, 강민아, 하은희, 신현상 (2014)

한국은 특히 아시아와 아프리카 지역에 국제보건의료 ODA 활동을 집중해왔다. 두 지역에 대 한 총 규모는 한국의 전체 국제보건의료 $\mathrm{ODA}$ 의 $81 \%$ 에 달하고 있는데, 아시아 지역에는 $45 \%$ 정 도가 집중되어 있고, 나머지 $36 \%$ 는 아프리카 지역에 치중하고 있다. 주요 분석 자료는 〈그림 2〉 에 나타난 바와 같다.

〈그림 2〉 국제보건의료 ODA 지역별 분석

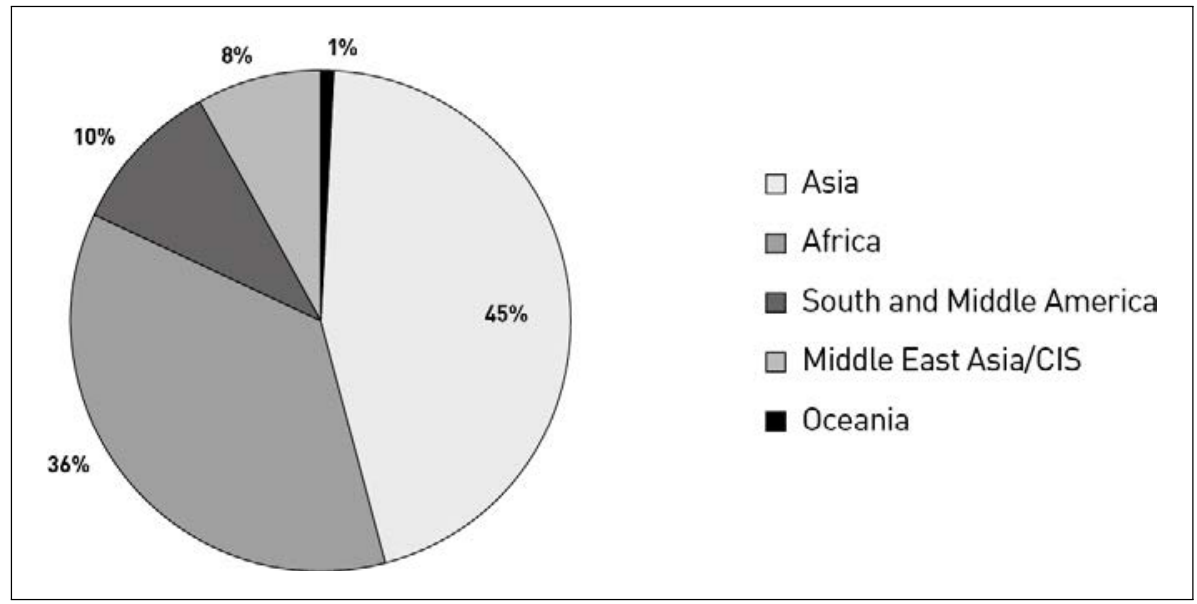

출처: 김은미, 안명옥, 오충현, 강민아, 하은희, 신현상(2014)

아시아 지역 내에서 한국의 ODA 활동은 첫 번째로는 보건 분야에, 두 번째로는 물과 위생 분 야, 세 번째로는 모자보건 분야에 집중하여 왔다(〈그림 3〉 참조). 
〈그림 3〉아시아 지역 내 분야별 프로젝트 건수

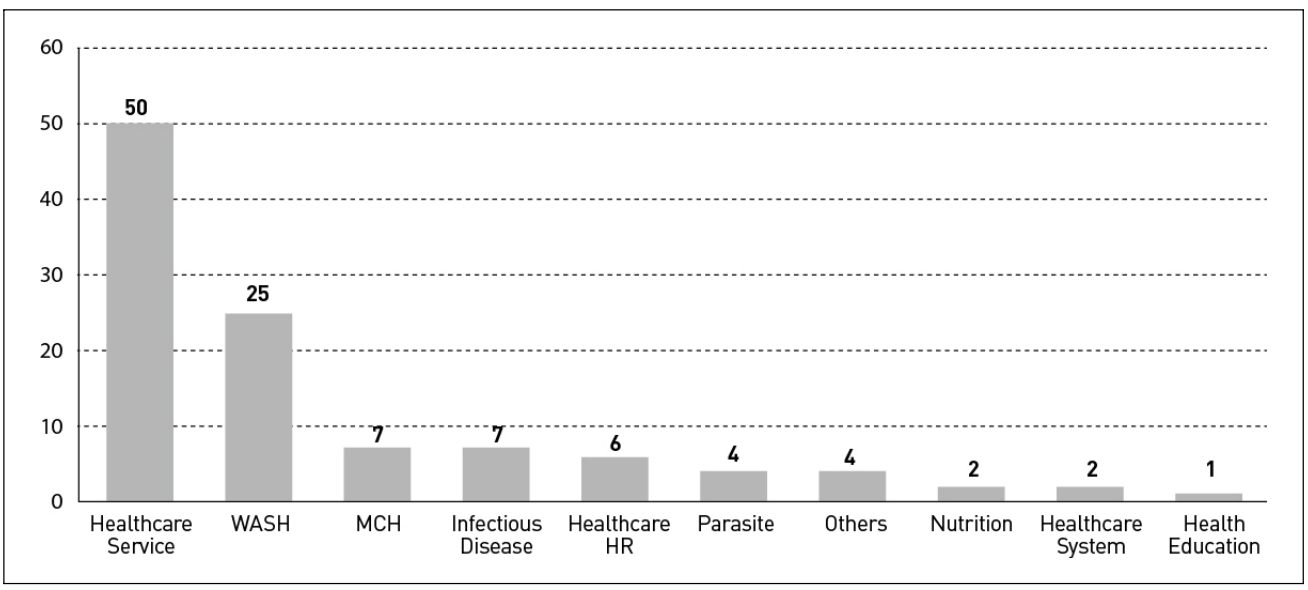

출처: 김은미, 안명옥, 오충현, 강민아, 하은희, 신현상 (2014)

아시아 지역 내 분야별 $\mathrm{ODA}$ 총액을 비교하면 보건분야에 집중해왔고, 다음으로는 전염성 질 환에, 그 뒤를 이어 모자보건 분야에 집중하여 투입해왔다. 이 사업들은 무상원조 사업들이며 따 라서 양허성 차관을 담당하고 있는 $\mathrm{EDCF}$ 의 활동은 포함되지 않았다.

아프리카 지역에 대한 한국의 국제보건의료 ODA 가운데 무상원조는 주로 전염성 질환에 치중 하여 왔고, 다음으로는 모자보건, 그 뒤를 이어 기생충 분야에 집중하고 있다(〈그림 4〉참조).

\section{〈그림 4〉아프리카 국제보건의료 ODA 프로젝트 총액}

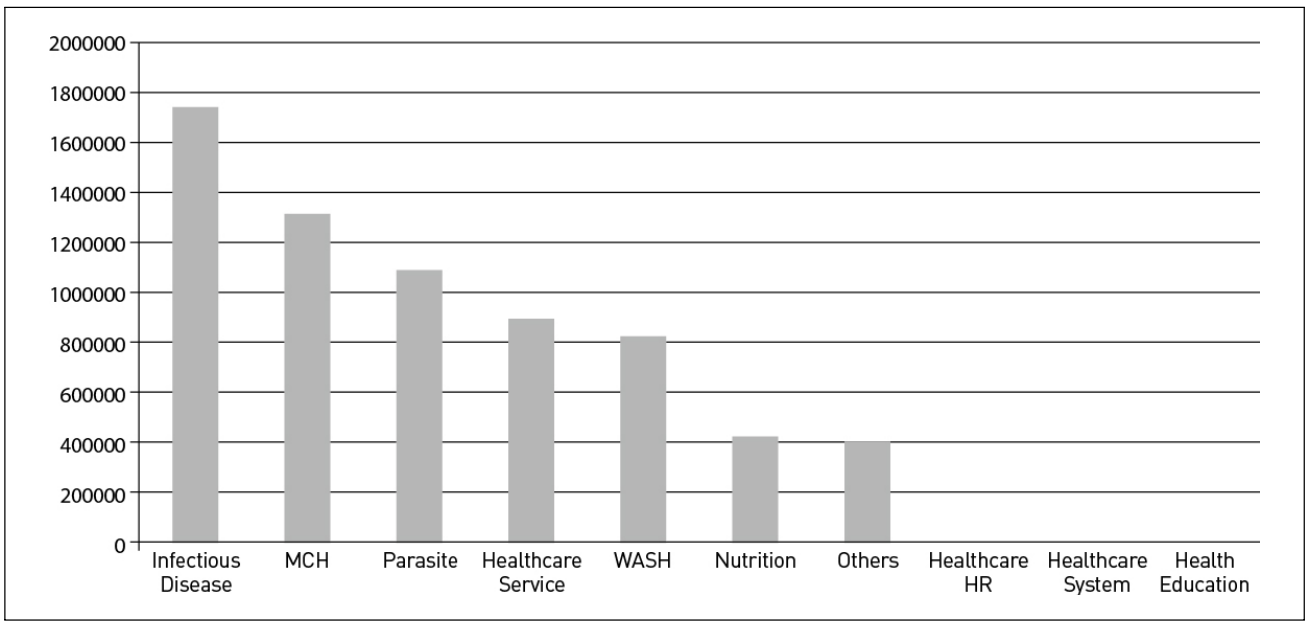

출처: 김은미, 안명옥, 오충현, 강민아, 하은희, 신현상 (2014) 
국제보건의료와 관련된 한국의 $\mathrm{ODA}$ 활동은 전반적으로 아시아와 아프리카 지역에 집중하여 왔다. 아시아 지역에서는 보건분야, 물 및 위생, 모자보건의 순서로 프로젝트를 집중하여 왔고, 투입한 예산은 보건분야와 전염성 질환, 모자보건의 순서로 프로젝트 수에 비해, 전염성 질환에 많은 투자를 해왔음을 알 수 있다. 반면 아프리카 지역은 전염성 질환, 모자보건, 기생충 등의 순 서로 $\mathrm{ODA}$ 프로젝트를 집중하여 왔고, 총액은 전염성 질환, 모자보건, 기생충 등의 순서로 투입 하여, 프로젝트 베이스로 예산이 사용되었음을 알 수 있다.

한국은 아시아와 아프리카 지역에 활발한 $\mathrm{ODA}$ 활동을 펼쳤지만, 아쉽게도 몇 가지 문제점이 발견되었다. 첫째, 국제보건협력의 총 예산이 다른 $\mathrm{OECD}$ 공여국에 비해 적은 편으로 한국이 이 분야에서 규모로 영향을 미치는 데는 한계가 있음을 확인할 수 있었다. 둘째, 국제보건협력과 관 련하여 한국의 $\mathrm{ODA}$ 는 한국의 특성이 잘 드러나지 않아, 어떤 특정 사업이나 세계적으로 주목받 는 어젠다나 이니셔티브를 제시하지 못 하고 있는 것으로 보인다. 향후 한국이 세계적으로 국제 보건협력 분야에서 활동하기 위해서는 규모의 증대와 더불어, 중요한 이니셔티브를 개발하여 한 국이 나름대로 국제보건협력에서 중요한 역할을 할 수 있을 것으로 기대한다. 특히, 한국의 ODA 규모가 계속 증가 추세에 있지만, 다른 거대 중요 공여국에 비해서 아직 규모에서는 한계가 있으 므로 중요 이니셔티브 및 사업들을 발굴하는 것을 제안한다.

\section{IV. 세계 글로벌 보건협력의 사각지대 분석}

세계의 보건의료 분야에서 어떠한 사각지대가 있는지를 분석하기 위해서 본 연구진은 여러 국 내외 보고서와 연구 결과를 살펴보았다. 수많은 연구가 있었으나, 본 연구에서는 21 세기에 전 세 계가 합의를 하고 이행하기 위해 전 지구적 노력을 기울였던 MDGs를 중심으로 살펴보았다.

21세기를 맞이하면서 국제사회는 지구촌 빈곤문제를 해결하기 위해 새천년을 여는 2000년에 $\mathrm{UN}$ 에 모여서 공동 대응을 약속했던 MDGs는 2015년 그 목표 달성의 해를 맞이하여 종료되었다. 전 세계의 지도자들이 집결하여 합의했던 MDGs의 8개 목표들은 과거 어느 목표보다도 국제사회 의 관심을 받으며 개발도상국의 빈곤감소와 사회적 발전에 많은 성과를 가져왔다.

특히 주목할 것은 $\mathrm{MDGs}$ 의 8개 목표 가운데 건강과 보건에 관련된 목표가 다수였고 이는 전 세계가 이 목표가 개발도상국의 빈곤 퇴치와 경제 및 사회 발전에 중요하다는 공통의 인식을 반 영한다고 하겠다. 2001년부터 2015년까지 MDGs 이행 노력을 통해서 개발도상국, 특히 최빈국 의 위생환경, 질병, 모자보건을 중심으로 전 세계의 수많은 국제기구, 정부들과 비정부기구와 Bill 
\& Melinda Gates Foundation 등이 많은 노력을 기울여왔다. 전체적으로 볼 때 많은 성과가 있 었고 특히 전 세계 최빈곤 인구의 감소, 초등교육의 보급 등 여러 목표는 비록 지역별 편차가 존 재하나 많은 성과를 냈다(UN, 2015).

그러나 8개 목표 중에 의료, 보건, 건강과 관련된 MDGs 4 번째 목표인 '영유아 사망률 감소'와 5 번째 목표인 '모성건강 증진'은 전반적으로 목표 달성에 미치지 못한 것으로 나타났다. 이는 8개 목표 중 가장 취약한 것으로 나타났다. MDGs 4번째 목표인 '영유아 사망률 감소'는 1990년 대비 2015년 영유아 사망률을 $2 / 3$ 가량 감소시키는 것을 목표로 설정된 것으로, 전 세계적인 인구증 가에도 불구하고 영유아 사망률이 1,260 만 건에 달했던 1990 년에 비해 2012 년에는 660 만 건으 로 감소하였으나 오세아니아 지역을 제외한 대부분 지역에서는 1990년 대비 2015년의 5세 미만 영유아 사망 감소율이 $50 \%$ 에 그친 것으로 나타났다(UN, 2015). 2015년 한 해에만 매일 16,000 명의 5 세 미만 영유아가 사망하고 있는 바 이 추세로는 목표 달성까지 향후 10 년 정도가 더 걸릴 것으로 예상된다(UN, 2015). 또한 영유아 사망률의 전체 추이는 감소하였으나 사하라이남 아프 리카의 경우 영유아 사망률이 선진국 평균의 10 배가량 높아 지역 간 불균형이 극심한 것으로 보 인다. 영유아 사망의 원인은 대부분 설사, 말라리아, 폐렴 등 예방 가능한 질병인 바, 적절한 의 료지원을 통해 신생아와 산모의 사망률 감소와 건강 증진을 위한 적절한 조치가 필요하다.

MDGs의 5번째 목표인 '모성건강 증진'은 1990년 대비 2015년의 모성 사망률을 3/4으로 감소 시키는 것을 목표로 설정했고, 1990년부터 2013년까지 전 세계적으로 모성 사망률이 $45 \%$ 감소 하는 성과를 거두었다. 실제로 동아시아와 북아프리카 및 남아시아에서의 산모사망률은 기존수치 의 $2 / 3$ 까지 감소하였고, 전 세계의 모성 사망비는 2013 년 출생아 100,000 명 당 210 명으로, 1990 년의 380 명에 비하여 감소하였으나, 2013년을 기준으로 매일 800명의 산모가 사망하고 있 으며, 이중 86\%는 사하라 이남 아프리카와 남아시아 지역에서 발생하고 있다(UN, 2015). 모성 사망률도 영유아 사망률에서와 같이 지역 간 불균형이 심각한 것으로 보여진다(UN, 2015). 특히 산모의 사망은 적절한 교육과 의료서비스에 의해 예방가능하나 많은 경우에는 임신 및 출산과정 에서 의료 혜택을 받지 못해 과다 출혈이나 감염과 같은 부작용에 의해 사망하는 바, 모성 사망 률을 줄이기 위한 조치가 여전히 시급한 것으로 사료된다.

이 두 목표의 미달성에는 여러 원인이 있겠으나, 최근 연구결과는 영유아 건강과 모성건강에 대한 MDGs의 접근방식에 문제가 있었음을 제시하고 있다. 즉, MDG 5 번째 목표의 달성을 위해 가임여성의 연령을 18 세 이상으로 결정하여 접근함으로써 개발도상국에서 자주 발생하는 조혼, 조기 임신, 다임신, 청소녀기의 영양 부족 등, 청소녀기에 이미 건강이 위협을 받고 어린 나이에 임신을 함으로써 본인의 건강 뿐 만 아니라 아기의 건강에도 적신호가 켜지고 있음을 간과한 것 으로 보인다. 이미 18세 미만의 소녀들이 임신과 출산을 경험하고 있으며 이에 따라 여러 모성질 
환에 노출될 뿐 아니라 사망에 이르는 등 심각한 상황에 처해있다. 특히 고위험 산모로 분류되는 15 세 미만 소녀들의 임신과 출산은 본인들의 건강과 생명뿐만 아니라 태아 및 영아의 건강과 생 명에도 큰 영향을 미치고 있다.

그럼에도 불구하고 소녀들은 대부분의 국제보건의료사업에서 제외되거나 청소년을 대상으로 하 는 사업에서도 수혜를 받지 못하는 등 국제보건의료영역에서 사각지대에 놓여있다. 또한 이 문제 는 보건과 의료혜택만을 제공함으로써 해결되는 것이 아니라, 보다 근본적으로 소녀들의 조기 결 혼, 조기 임신과 출산을 방지하기 위한 다각적이고 포괄적인 접근이 필요함을 시사한다. 또한 경 우에 따라서 소녀들의 임신이 성폭력에 의한 것일 수도 있는 바, 소녀건강의 문제는 그 문제 인 식, 원인 분석과 문제 해결에 있어서 포괄적이고 다층적인 접근을 필요로 한다.

소녀건강을 살펴보기에 앞서서 소녀의 연령을 사회문화적, 임상학적 관점에서 정의하고자 한 다. 먼저, 사회문화적으로 소녀는 18세 미만의 여자아동으로 정의하고 있으며, 유엔 아동권리협 약(Convention on the Rights of the Child)에서는 아동을 18세 미만으로 정의하고 이들의 생 존, 발달, 보호, 참여에 관한 기본 권리를 명시하고 있다(Office of the United Nations High Commissioner for Human Rights, 1989). 이에 따라 '소녀'는 18세 미만의 여자아동으로 정의 할 수 있으며, 유년부터 청소년 시기까지에 걸친 세대를 의미한다고 보겠다. 소녀건강은 특히 성, 생식건강 증진에 초점을 맞춰 지원할 필요가 있기에 이러한 문제를 겪고 있는 소녀들의 연령에 집중할 필요가 있다. 따라서 임상학적으로 볼 때 소녀들이 초경을 시작하는 연령은 평균 12 세로, 사춘기 시작연령은 그보다 2-3년 이전인 9-10세로 보고 있다(Anderson et al., 2003; Jones et al., 2009; WHO, 2011b). 이에 소녀들이 성에 노출되기 전인 9세부터 기본적인 성교육과 정 보제공, 사회적/정서적 학습, 부모와 지역사회의 인식변화 등을 통해 소녀들이 성, 생식건강을 지 키고 학교와 사회생활을 할 수 있도록 지원해야 한다(Sommer \& Benkatraman, 2014). 따라서 본 연구에서 소녀연령의 정의는 임상학적 관점에서 소녀라고 정의되는 9 세부터 사회문화적 관점 에서 소녀라고 정의되는 18세 미만까지의 여성아동으로 한다.

소녀들의 건강 불평등 문제를 살펴보고자 한다. 소녀들은 건강 불평등으로 인해 적절한 지원과 의료서비스를 받지 못하는 것으로 나타난다. 이러한 건강 불평등은 사회적 구조 및 불이익에 기 반을 둔 것이며, 국제적으로 건강 불평등을 해결하기 위한 방향을 제시하고 있다. 세계보건기구 (World Health Organization, 이하 WHO)는 2011년 10월 인류의 삶과 건강을 위한 국제적인 노력으로 '보건의 사회적 요인에 대한 리오 정치적 선언(Rio Political Declaration on Social Determinants of Health)'을 통해 전 인류의 형평성(All for Equity)을 주창한 바 있다(WHO, 2011a). 본 회의에서는 건강 불평등을 완화시키기 위해서 총 다섯 가지의 활동 계획을 수립하였 다(WHO, 2011a). 첫째, 발전된 정치적 거버넌스를 통하여 인류의 보다 나은 건강과 개발을 도 
모할 것. 둘째, 정책 형성과정 및 실행과정에서 시민들의 참여를 도모할 것. 셋째, 보건분야의 우 선순위를 건강 불평등 완화로 세울 것. 넷째, 국제적인 거버넌스와 협력을 도모할 것. 다섯째, 책 임 의식을 향상시키고 액션 플랜 이행여부를 주기적으로 확인할 것. 이에, 사회, 경제, 환경, 빈 곤, 불평등 문제들에 따라 나타날 수 있는 건강 격차를 해소하고 다원적 접근체계를 구축하여 양 질의 보건복지 시스템을 건설할 것을 권고하였다(WHO, 2011a).

이에 더불어 기존 연구들은 건강 불평등을 해결하기 위해 불평등을 야기하는 사회적 요소를 분 석하는 노력을 해왔으며 주로 18 세 이상의 성인 여성을 대상으로 진행해왔다. 이를 통해 성인 여 성들은 의료서비스를 제공받는 과정에서 성인 남성과 비교했을 때 겪는 불평등의 문제가 심각한 것으로 나타났다. 예를 들어, 결핵은 열악한 빈곤 환경에서 가장 자주 나타나는 질병으로서 개도 국 여성들의 대다수가 절대 빈곤을 경험하기 때문에 결핵에 노출될 확률이 높은 것으로 밝혀졌다 (Govender and Penn-Kekana, 2008). 베트남이나 방글라데시의 경우 대다수의 젊은 여성들이

제 I 장

\section{개} 결핵 환자일 확률이 높은 것으로 보이나 대부분의 여성들은 인근 마을이나 사회에 자신의 질병이 알려질 경우 결혼을 못 하거나 사회적으로 고립될 수 있다는 두려움 때문에 알리지 못하는 것으 로 나타났다. 이로 인해 많은 여성들이 의료서비스를 제공받지 못해 적절한 치료를 제때 받지 못 하고 있는 것으로 나타났다(Govender and Penn-Kekana, 2008).

또한 성인 여성들의 건강 불평등에 관한 연구를 통해 환자와 의료서비스 제공자 사이에서도 여 성을 상대로 한 불평등의 사회적 결정요소가 있음을 확인하였다. 특히, 가부장적 사회구조나 종교 적 의식이 강한 개도국에서는 환자와 의료서비스 제공자 간의 성 일치성이 중요한 요소 중 하나 로 인식된다(Rizk, D. E., El-Zubeir, M. A., Al-Dhaheri, A. M., Al-Mansouri, F. R., and Al-Jenaibi, H. S, 2005). 태국의 산모들의 경우 출산 전 검진은 여성 조산원 혹은 여성 의사로 부터 받기를 희망하는 경향이 있는데 이는 남성 의료서비스 제공자에게 자신의 신체의 일부를 노 출할 경우 상당한 수치심을 느끼기 때문이다(Nigenda et al., 2003).

개도국 소녀들은 성인 여성들에 비해 더 심각한 건강 불평등을 겪고 있는 것으로 보인다. 대부 분의 개발도상국에서는 청소년, 특히 소녀들을 위한 보건의료서비스가 매우 부족한 실정이며, 보 건소가 있더라도 이들의 건강 문제를 다루기에 적절치 않거나 필요한 시설이 부족하여 많은 이들 이 이용할 수 없는 상황이다(Fatusi and Hindin, 2010). 또한 소녀들을 포함한 청소년들은 보건 소 출입으로 인해 주변 사람들에게 신체적 혹은 성적으로 문제가 있는 것으로 낙인이 찍힐 것을 두려워하거나, 물리적으로 보건소의 거리가 멀고 방문 시간이 맞지 않는 등 서비스를 제공받는 것이 제한되고 있다(Tylee et al,, 2007). 소녀들은 성인 여성들에 비해 생식건강과 관련 의료 서 비스를 받는 것에 불평등을 겪고 있는데, 기존 연구에 따르면 저개발국가 소녀들은 성인 여성에 비해 출산 전 진료 받는 비율이 상당히 낮으며 피임법 활용률도 낮은 것으로 나타난다(Hidalgo, 
Chedraui and Chavez, 2005; Kongnyuy et al., 2008; MacQuarrie, 2014).

따라서 소녀와 모성, 영유아 건강증진을 위해 소녀들을 위한 보건의료서비스 제공이 시급하며, 소녀들의 건강을 위협하는 사회적 요인들을 분석하여 개선방안을 마련하는 것이 필요하다. 특히 개도국의 소녀들이 겪고 있는 건강 불평등을 완화시킴으로써 장기적인 시점에서 소녀건강문제와 관련한 포괄적인 사회 문제들을 해결할 수 있으며, 그 중 성생식 건강에 대한 불평등 완화는 향 후 소녀들의 조기 결혼, 임신 및 출산을 방지하고 건강을 증진시켜 MDGs 목표 4와 MDGs 목표 5 가 중점을 두었던 아동사망률을 감소시키고 모성 건강에 기여할 수 있을 것이다.

소녀들의 건강 문제는 아동기나, 성인기의 건강 및 건강 불평등의 문제와는 질적으로 다르기 때문에 소녀들이 겪는 건강문제와 사회적 결정요소를 분석하는 것이 매우 중요하다. 이미 소녀들 은 조기 결혼, 조기 임신, 성폭력, 영양실조, 교육 기회 박탈을 경험하고 있지만 이들을 위한 적 절한 서비스와 지원은 미비한 상태이다. 따라서 개도국 소녀들을 대상으로 건강 불평등을 악화시 키는 사회적 결정요소들을 분석하고 이를 해결하기 위한 포괄적인 해결책을 제시하는 연구가 활 발히 진행되어야 한다. 이러한 연구 결과를 바탕으로 적절한 보건의료서비스, 영양보급, 교육기회 의 제공과 더불어 성폭력 방지를 비롯한 포괄적인 해결 방법들이 시행되어야 보다 효과적으로 소 녀들의 보다 나은 삶을 제공해주는 환경을 만들게 될 것이다.

\section{V. 에티오피아의 Youth Friendly Service for Sexual and Reproductive Health 사례연구}

본 연구진은 포괄적인 소녀건강과 교육에 대한 글로벌 보건 협력 분야의 중요성을 파악하고, 현재 한국정부가 참여하고 있는 유사 사업을 분석하기로 하였다. 이에 본 연구진은 KOICA의 지원을 받아 2015년 8월 10일부터 15일까지 에티오피아를 방문하여 'Young People's Empowerment in Reproductive Health Through Awareness and Service Expansion in Ethiopia 사업' 추 진 현황을 모니터링 하였으며 이를 통해 작성한 'YERASEE 사업현장 방문 결과보고서'를 참고하 여 사례연구를 진행하였다. 본 사례연구는 향후 한국이 포괄적 소녀건강과 교육 ODA 사업을 본 격적으로 확대하는데 있어서 중요한 시사점을 줄 수 있을 것이다(김은미·정혜원 · 이지은 · 임세 은, 2015).

최근 국제사회는 국제보건의료영역에서 청소년, 특히 소녀들이 보건서비스의 사각지대에 있음 을 인식하고 다양한 사업을 시도하고 있다. 또한 MDGs에서 미진한 결과를 보인 '영유아 사망률 
감소'와 ‘모성건강 증진'은 이미 임신과 출산을 겪고 있는 개도국 소녀들과 긴밀한 연관이 있으며, 2016년부터 MDGs의 후속체제로 시작된 지속가능개발목표(Sustainable Development Goals, 이하 $\mathrm{SDGs}$ )에도 전 세대 전 연령의 건강증진 뿐만 아니라 모성 및 영유아 건강, 질병확산 감소 가 주요 세부목표로 설정되어 있는 바, 이를 달성하기 위해서도 소녀건강증진에 주목하는 것이 중요할 것으로 사료된다.

Pathfinder International은 지난 40년 동안 아프리카와 아시아 등 전 세계 약 30개국에서 청소년 및 젊은이들의 생식보건 증진을 위해 사업을 추진해온 기관으로 공여국 정부, 국제기구, 기업, 재단, 시민단체 및 지역사회등과 긴밀한 협력을 통해 청소년 건강 증진에 기여하고 있다 (Pathfinder, 2016). 에티오피아의 경우 Pathfinder International-Ethiopia (PI-E)가 국가 내 청소년들의 생식보건 문제와 서비스의 필요성을 인식하였고, 이를 위해 2005년부터 에티오피 아 보건부와 함께 '청소년 생식보건 사업(Adolescent and Youth Reproductive Health

제 I 장

\section{개} Program)'을 시작하였다(Asnake, Mengistu, Claire B. Cole, Gwyn Hainsworth, Jill Hodges, Worknesh Kereta, Kidest Lulu, and Callie Simon, 2012). 본 사업은 모잠비크에 서 1999년부터 진행되고 있는 'Geracao Biz 사업’을 바탕으로 개발된 것으로 이는 Pathfinder가 지원하고 있는 다부문적 청소년 생식보건 사업(Multisectoral Adolescent and Youth Sexual and Reproductive Health Program)이 성공적으로 진행되고 있다고 평가되었기 때문이다 (Asnake et al, 2012; Hainsworth and Zilhao, 2009).

$\mathrm{KOICA}$ 는 에티오피아 청소년들의 건강증진에 기여하고자 2014년부터 에티오피아 정부 및 PI-E와 협력하여 ‘청소년 생식보건 증진 사업(Young People's Empowerment in Reproductive Health Through Awareness and Service Expansion in Ethiopia, 이하 YERASEE)'을 지원 하였다. 본 사업은 PI-E를 통해 80개의 보건소에서 청소년 친화적인 서비스(Youth-Friendly Service, 이하 YFS)를 제공하고 총 200,000 명의 청소년에게 서비스를 지원하는 것을 목표로 하 였다(Pathfinder, 2015). 또한 사업을 추진하는 직원 및 보건 전문가들이 청소년 친화적인 태도 를 갖추어 청소년 및 젊은 환자들에 적합한 보건의료 서비스를 제공하고, 생식보건 관련 정보 및 교육을 통해 청소년 및 젊은 청년들에게 올바른 생식보건지식을 제공하는 것을 주요 목표로 진행 되었다(Pathfinder, 2015).

YFS 센터에서는 일반적으로 보건서비스 제공, 또래교육, 커피 세레모니, 행동변화 프로그램 등을 주요 활동으로 진행한다. 보건서비스의 경우, 보건서비스 제공자가 전문적인 상담, 치료, 정 보 제공, 및 약 처방 등을 하며 생식보건 관련 상담(HIV 상담 및 검사, 부인과 검사, 임신 테스 트, 피임 관련 상담, 성폭력 상담, 성병 관련 상담, 유산 후 관리, 출산 전/후 관리, 수직감염 예 방 등)을 포함한 일반적인 보건 서비스도 제공한다. 또한 이들은 전문적인 의료상담 외에도 청소 
년들과의 소통을 통해 청소년들이 YFS 센터에 친근감을 느낄 수 있도록 돕고 있다. 또래교육이 란, 비슷한 나이의 청소년들이 교육을 받고 '또래 교육자'가 되어 주변 친구들에게 보건지식을 전 달하는 것으로, 거의 성/생식보건과 관련된 내용을 교육하고 상담하는 역할을 한다. 또래교육자는 보통 센터마다 25 명의 15 세 -20 세 사이의 청소년들로 구성되어 있으며 학교에 재학 중인 학생 및 학교를 다니지 않는 청소년들이 포함된다. 또래교육자는 의사소통기술, 리더십, 건강관련 정보 등 을 교육받은 후에 학교나 일상생활에서 만나는 청소년들에게 건강과 관련된 정보를 제공한다. 또 한 이들은 센터에 방문한 청소년들에게 그룹 상담을 해주거나 교육을 제공한다. 커피 세레모니는 에티오피아의 전통적인 행사로서 YFS 센터를 알리고 청소년들의 서비스 이용을 유도하기 위해 사용되고 있다. 커피 세레모니는 정기적으로 약 10 일-15일에 한번씩 진행되며, 청소년들뿐 아니 라 부모들을 포함한 지역 주민들도 참여하여 YFS의 중요성을 알리고 인식을 제고하여 청소년들 이 센터에 방문할 수 있도록 도와주도록 하는 역할을 하고 있다(김은미·정혜원 · 이지은 · 임세 은, 2015).

본 ‘에티오피아 청소년 생식보건 증진 사업’은 청소년들에게 생식건강에 대한 올바른 정보를 제 공하고, 전반적인 건강문제를 다루면서 의료 서비스에 접근이 제한되었던 청소년들이 비교적 쉽 게 센터를 방문할 수 있게 되었다는 점에서 긍정적으로 평가된다. 뿐만 아니라 소녀들은 상담 및 또래교육 등을 통해 권한이 강화되었다고 하였으며 자신감을 얻은 모습을 확인 할 수 있었다. 그 러나 여전히 소녀들이 직면하고 있는 성차별적인 문화와 관습이 남아있어 조혼과 소녀임신이 계 속되고 있어 이를 변화시키기 위한 노력이 필요하며, 15 세 미만의 소녀들은 YFS 센터 이용률이 매우 낮아 이들의 건강에 지원하기 위한 별도의 개선책이 마련되어야 한다고 사료된다.

\section{VI. 개발도상국의 포괄적 소녀건강과 교육에 있어서 한국의 글로벌 리더십}

한국이 그 동안 국제보건의료 분야에서 그 규모도 비교적 적고 특징이 잘 드러나 있지 않았다. 또한 개발도상국을 대상으로 한 MDGs 이행 결과를 분석해 보았을 때 아직도 영유아 건강과 모 성건강 증진의 목표 달성이 가장 취약한 것으로 나타났다. 특히 MDGs를 비롯한 국제보건의료 사업들에서 모성건강과 영유아 사망률 저하를 위해 접근한 가임여성의 연령대가 18 세 이상으로 되면서, 18 세 미만 소녀들은 모성건강과 영유아 건강 문제에 직면해 있으면서도 적절한 지원을 받지 못하고 있는 것으로 파악되었다. 따라서 본 연구를 통해 9 세부터 18 세 미만에 이르는 소녀 들에게 초점을 맞추어 모자보건, 영유아 건강 및 여성 건강을 증진하기 위한 것으로 전세계의 국 제보건의료 사업이 관심을 기울이고 지원을 증대해야 할 것으로 사료된다. 
향후 후속 연구를 더 진행해야 하겠으나, 전세계적으로 볼 때 아직 소녀건강에 대한 관심은 초 기 단계에 있으나, 2015년 3월 미국의 Obama 대통령이 미국 원조의 주요 이니셔티브로 'Let Girls Learn'을 발표하면서 세계의 관심이 소녀들의 문제로 움직이고 있는 것을 알 수 있다. 또 한 영국의 DFID등 다른 공여국들과 전통적으로 여성과 아동에 대해 관심과 지원을 해오고 있는 국제기구들과 비정부기구에서도 이에 대한 관심이 서서히 증가하고 있다. 한국이 이 문제의 심각 성을 세계에 알리면서 전세계의 지원을 이끌어내서 세계의 보건협력의 중요한 난제인 영유아 건 강과 모성건강의 증진에 기여하고, 더 나아가서 개발도상국의 사회 및 경제 발전에 기여할 수 있 기를 바라면서 다음의 제안을 한다.

$\mathrm{MDGs}$ 의 4,5 의 문제를 해결하기 위한 시작점으로 소녀건강을 중점으로 하여 통합적 및 전반적 으로 국제보건의료와 관련하여 한국의 $\mathrm{ODA}$ 활동을 점차 확장해 갈 필요가 있다. 또한 한국은 세 계의 보건의료 체제(Global Healthcare System)의 개편에 주도적으로 참여하여, 국제기구와 국

제 I 장

\section{개 제 재단 및 공여국과의 협력 사업을 확대할 필요가 있다고 본다. 글로벌 공중 보건(Global Public Health) 분야에 ODA 사업을 확장해야 하며, 한국의 특장 점을 살린 의미 있는 글로벌 공중 보건과 관련한 $\mathrm{ODA}$ 의 비전을 수립하고, 사업을 발굴할 필요가 있다. 이에 한국은 통합된 원조 시스템 아래에 국제보건과 관련한 원조기관들이 상호 협력하여 ODA 활동을 해야 할 필요가 있다고 본다.

이러한 관점에서 2015년 9월 UN 개발정상회의에서 대한민국 정부가 발표한 개발도상국 소녀 들의 보건 및 교육을 위한 '소녀들의 보다 나은 삶(Better Life for Girls)' 구상에 기반을 두어, 구체적인 사업의 종류를 제안한 것은, $\mathrm{SDGs}$ 를 성공적으로 달성하는 데 있어 중요한 전제조건인 소녀건강을 증진시킴으로써, 개도국 내의 지속적인 환경, 경제, 그리고 사회발전에 기여할 수 있 다고 사료된다. '소녀들의 보다 나은 삶'의 구상은 크게 다음 3 가지 핵심제안으로 정리될 수 있다: (1) 여성건강, (2) 소녀건강, (3) 소녀교육. 아래에서 각 주제에 대해 간단히 살펴보고 본 장의 마 지막에 이 분야에서 어떻게 한국이 글로벌 리더십을 가지고 가야 할지에 대해 제언을 한다.

\section{1. 여성건강의 중요성}

여성의 건강은 모성건강과 연결되어 자녀건강에 필수적 전제임에도 불구하고, 그들의 건강에 대한 이해가 부족하며 다른 가족구성원에 비해 우선순위의 뒤편에 자리매김하고 있다. 여성은 임 신, 출산과 관련된 위험, 그리고 여성생식기계 암, 감염 등과 같은 여성 특유의 건강문제 뿐 아니 라, 성 상품화, 성폭력, 성매매 등의 사회문화적 요인으로 인해 정신건강문제에도 취약한 위치에 있다. 여성건강은 여성은 인구학적, 신체적 특성과 여성교육, 경제, 노동, 문화, 사회 환경과 
가족 내 역할과 위치 등에 의해 건강에 긍정적인 영향보다는 부정적인 영향을 더 많이 받는다(안 명옥, 2014).

\section{2. 소녀건강의 중요성}

$\mathrm{WHO}$ 에 의하면 청소년은 10 세에서 18 세까지의 인구를 일컫는다(WHO, 2014). 현재 전세계 73 억 명의 인구 중 청소년은 약 12 억 명으로, 이들 중 $85 \%$ 가 사회경제적 기반이 열악하고 건강 문제가 만연한 개발도상국에서 살고 있다(UNFPA, 2008; WHO, 2014). 개발도상국의 청소년들 은 건강문제에 취약하며, 특히 성생식건강 문제에 많이 노출되어있다. 2025년에는 전세계 청소년 인구가 약 7,200 만 명에 달할 것으로 예상될 정도로 급증하고 있어, 그들의 건강문제에 대한 적 절한 예방과 치료가 필요하며 건강보건학적 관점에서 매우 중요한 인구집단으로 자리매김했다. 또한 청소녀의 건강상태 및 건강관련 행동이 이후 임신, 출산에 영항을 미치므로 '소녀건강'은 모 성건강을 향상시키고 영유아 사망률을 감소시키는데 매우 중요한 역할을 하므로 소녀건강을 증진 하는 접근법이 고안되어야 할 것이다(Fatusi and Hindin, 2010, Marmot et al., 2008).

청소년기는 감수성, 도덕성 등 정신적 특성이 생성되고 정체성이 발달하며, 음주, 흡연, 약물 등 건강과 관련된 행동이 형성되는 시기로, 향후 성인의 건강양상을 결정짓는 중요한 시기이다 (Sawyer et al., 2012). 청소년들은 나이, 결혼유무, 학업여부, 경제사회적 요소가 개인별로 큰 차이를 보이고 있어, 단일한 접근법으로 그들의 건강문제를 개선할 수 없다. 특히 소녀들의 건강 문제는 개인의 지식부족이나 잘못된 행동에 의해 발생하는 것이 아니며, 대부분 가족과 집단, 사 회의 문제로 인해 발병된다. 소녀건강은 이들의 미래 뿐만 아니라 가족, 집단, 사회의 미래에도 영향을 미치는 중요한 문제이다. 소녀들은 생리 등의 신체적 변화를 겪을 뿐 아니라 성적 위험에 노출되기 쉬우나, 영유아들에 비해 가족이나 지역사회의 보호를 받지 못하며, 건강과 관련된 정보 나 서비스를 제공이 제한되어 있어 건강에 있어서 주목해야 할 집단이다(Temin and Levine, 2009).

또한 위에서도 살펴본 바, 소녀들의 의료 기관 출입은 사회적 편견으로 인해 많은 제약을 받고 있다(Tylee et al., 2007). 또한 개발도상국의 경우, 여성들의 초혼 연령이 낮고 피임 사용률이 낮아 소녀 출산율이 높으며, 이는 산모 사망률에 중대한 요인이 되고 있다(국가개발협력위원회, 2012). 소녀기의 임신은 산모 본인 뿐 아니라 영유아 건강에 부정적 영향을 미치며 심각한 경우 사망에 이르게 하는 결과를 초래한다. 소녀가 임신과 출산을 하는 경우, 가난과 영양 결핍, 적절 한 산전관리를 받지 못하며 신체발달이 완성되지 않은 경우가 많아 성인 임산부보다 산후 출혈, 비만, 정신 질환, 태아 및 신생아 사망, 산과적 누공 등에 노출될 위험이 더 높다(Fatusi and 
Hindin, 2010). 특히 12 세에서 20 세 미만의 소녀출산인 경우 자녀가 5 세 이하에 사망하거나 저 체중, 빈혈 등의 건강문제가 발생할 가능성이 높은 것으로 나타났다(Temin and Levine, 2009). 또한 소녀산모의 풍진, 에이즈와 같은 바이러스 감염, 비만, 영양 결핍증, 임신당뇨병 등의 질병 과 알코올, 흡연 등의 건강 관련 행동이 자녀들의 건강에 영항을 준다고 밝혀져있다(Abel, 1980 ; Bhutta et al., 2008; Pettitt et al., 1983; Pettitt et al., 1988). 특히 아프리카와 동남아 지역에서 어린 나이에 출산한 여성들이 성숙되지 않은 산도를 통하여 진통시간이 길어지는 폐색 출산(obstructed labor)이 있는 경우 태아사망률은 $95 \%$, 산모사망률이 $8 \%$ 가 된다. 폐색출산에 의해 질에 누관(vaginal fistula)이 생기면 소변과 대변이 계속 새기 때문에 부부생활 및 사회생 활이 어려워져 평생 사회경제적인 약점을 갖고 살아야 하는 등 그 문제가 심각하다(Tilahun et al., 2014). 따라서 소녀임신에 있어서 태아기와 출산전후의 태아에 대한 집중적 보건의료 서비 스를 제공하는 것이 모성건강 및 영유아 사망률을 개선하는 것이고, 이보다 더 중요한 것은 소녀 기에 결혼과 임신을 방지하여 소녀들이 어린 나이에 출산으로 인해 겪게 되는 여러 문제들을 예 방하는 방향으로 해결책을 찾아야 할 것이다.

에이즈 바이러스(Human Immunodeficiency Virus, HIV)에 감염된 청소년이 2012년에 210 만 명으로 새로운 HIV 감염자의 $1 / 7$ 이 청소년이다. 사회경제적으로 취약하고, HIV감염에 취약 한 소녀들은 HIV/AIDS에 대해 적절한 교육이 이루어지지 않아, 건강지식이 현저히 부족하다. 이 들은 보건의료서비스에 대한 접근성도 매우 낮으며, 조혼이 성행하고 있어 소녀시기에 성행위를 경험하게 된다. HIV에 감염된 소녀들은 성매매와 폭력에 노출되는 빈도가 높아져, 부모와 사회로 부터의 보호가 결여된 상태에서 살아가게 된다(UNAIDS, 2013). 양질의 의료 서비스와, 소녀친 화적인 HIV 및 성생식건강에 특화된 보건소에 접근하는 것만으로도 HIV 감염을 현저히 저하시 킬 수 있어 적극적으로 소녀들의 성행위감염증 문제에 개입할 필요가 있다. 또한, 적절한 HIV 감 염 여부 조사 및 상담, 그리고 성교육이 이루어지면 소녀들과 젊은 여성들을 가정폭력으로부터 보호할 수 있는 부수적 효과를 낳고, 이미 HIV에 감염된 소녀들이 건강상태를 유지할 수 있게 할 수 있다.

\section{3. 소녀교육의 중요성}

소녀들의 건강증진에 있어 교육은 필수요건이다. 앞서 설명한 바, 소녀들이 건강문제에 노출되 는 주요한 원인은 그들의 사회경제적 취약성에 기인한다. 근본적으로 소녀들의 역량을 강화하지 않고 소녀건강 문제에 접근하게 되면 단기적 성과로 이어질 확률이 높다는 점에서 소녀건강과 교 육은 병행되어야 한다. 교육은 개인의 역량을 개발할 뿐만 아니라, 개발도상국의 지속가능한 발전 
에 큰 기여를 한다. 교육은 소녀들에게 지식을 제공할 뿐만 아니라 본인과 자녀의 건강에 대한 지식, 자아의식 고취 및 역량강화로 이어지기 때문에 중요하다(Vander Kamp, 2004). 교육을 통 해 질병, 특히 성생식 건강문제에 가장 취약한 소녀들은 보건위생과 성교육을 통해 건강상태를 개선할 수 있고, 개발도상국에서 자주 발생하는 전염병과 성생식 질환의 위협으로부터 자신을 보 호할 역량을 키울 수 있게 된다.

학교가 소녀들에게 지식전달 이상의 역할을 한다는 단적인 예로는 지난 에볼라 바이러스가 확 산되었을 당시 시에라리온의 사례를 보면 잘 알 수 있다. 에볼라 바이러스 사태로 인해 시에라리 온의 학교들은 9 개월간 폐쇄되었다(Save the Children, 2015). 9개월 간 아동 및 청소년들은 어 떠한 공교육도 받지 못했으며 학교라는 안전한 공간으로부터 벗어난 소녀들은 성적학대의 위협에 서 벗어날 수 없었다. 실제로 이 기간에 시에라리온의 소녀들은 10 명 중 1 명꼴로 성폭행을 당했 으며, 이들은 성폭행으로 인한 조기임신 또는 사회문화적 제약으로 인해 학교로 돌아갈 수 없는 상황이다. 이처럼 교육은 지식전달 이외에도 개인의 건강과 안전을 보장하는 역할을 해서 소녀건 강 증진에서 교육의 역할은 대단히 중요하다(Save the Children, 2015). 여기서 교육은 성교육 만을 일컫는 것이 아니라 공교육을 포함한 큰 의미의 교육을 포함해야 한다. 학교에 소녀들이 접 근할 수 없었다는 이유만으로 성폭력과 임신에 노출되었다는 것은 학교 교육이 얼마나 소녀들의 건강권과 교육권에 있어서 중요하고, 이 들 문제들이 연결되어 있다는 것을 보여준다.

본 연구는 이처럼 소녀건강 증진을 실현하기 위해 소녀들에 대한 교육도 병행할 것을 강조한 다. 교육을 통해 소녀들의 자주권을 확보하고, 사회문화적 취약성을 해결하는 것이 소녀건강을 증 진하는 가장 효과적인 방법이다. 소녀교육을 통한 역량강화는 장기적으로 개발도상국의 경제사회 에 기여를 한다는 점에서도 SDGs의 달성에 중요하다고 하겠다.

지금까지 살펴본 소녀건강과 교육의 중요성을 통해 한국의 글로벌 리더십을 제언하고자 한다. 본 연구의 최우선 가치는 소녀들의 인권을 신장하는 것인 바, 소녀건강을 위한 포괄적 접근에 있 어서 최우선 원칙은 인권에 기반한 접근이다. 소녀인구집단에 대한 개입을 통합적이고 막연하게 하기 보다는 이들이 가지고 있는 특수성에 따라 접근법을 고안할 필요성이 중요시된다. 다시 말 해, 소녀는 그 시기 만의 특징을 가진 그룹이기 때문에 그 특징을 이해하고 접근하는 노력이 필 요하다. 따라서 개발도상국의 소녀들의 건강과 교육을 증진하는 사업을 발굴하기 위해서, 국제개 발전문가, 국제보건 전문가 및 의료인 뿐 아니라 청소년 전문가, 교육 전문가와 함께 사업을 진행 하는 것이 도움이 될 것이다. 또한 보다 많은 청소년들에게 서비스를 제공하기 위해 학교 및 지 역단체와 연계하는 방안도 고려되어야 할 것이다.

한국은 지난해 SDGs 체제 속에서 한국 정부가 펼쳐나갈 국제개발원조 사업으로 '소녀들의 보 
다 나은 삶(Better Life for Girls)' 구상을 제안하였다. 이는 MDGs에 이어 SDGs에서 포함하고 있는 종합적인 건강 목표를 이루기 위해 청소녀 건강에 대한 포괄적인 지원이 필요하다는 논리에 기반한다. 소녀건강 증진을 위한 다차원적인 접근을 통해 보건의료 서비스 향상과 교육 기회를 제공하고, 이를 통해 모성 및 영유아 건강 증진에 긍정적 영항을 줄 뿐 아니라 여성들의 권한 증진 및 성평등을 실현하여 개발도상국의 경제, 사회, 정치 발전에 기여할 수 있을 것이라 사료된다.

제 I 장

\section{개}

\section{VII. 결론}

한국은 전 세계에서 그 유례를 찾기 힘들 정도로 빠르게 최빈국에서 원조공여국으로 탈바꿈하 였다. 한 세대 안에 빈곤퇴치, 경제발전과 민주화를 이루어 냈으며 전쟁의 폐허 속에서 발전한 한 국은 많은 개발도상국들에게 귀감이 되고 있다. 본 연구에서는 특히 ‘글로벌 보건협력분야에서 한 국이 기여할 수 있는 분야가 무엇일까라는 문제의식에서 출발하여, 한국이 개발도상국 당시의 공 중보건 사업, 최근 공여국으로서 한국이 집행한 보건협력 $\mathrm{ODA}$, 또한 세계의 보건협력에서의 사 각지대에 대한 분석을 통해서 소녀들이 모성건강과 영유아 건강에 있어서 취약하다는 것을 발견 하였다. 9 세에서 18 세 미만에 이르는 개발도상국 소녀들은 조기 결혼, 조기 임신과 출산, 고위험 출산 등에 노출되어 있으나, 여러 이유로 인해 적절한 의료서비스에 접근이 제한되어 있고, 특히 공적개발원조에서도 간과되고 있다. 또한 소녀 임신과 출산 문제를 보면, 이것의 해결은 그들에게 의료서비스를 적절하게 제공하는 것도 중요하지만, 근본적으로 소녀기에는 소녀로서 소녀다운 삶 을 살 수 있도록 임신과 출산에서 자유로워야 한다는 인식에 기반을 두어야 한다고 사료된다. 따 라서 소녀건강 증진을 위한 해결책 중에는 소녀들에게 교육의 기회를 주어서 그들이 출산과 임신 으로부터 자유롭게 해주는 것이 중요하다고 하겠다.

이에 본 연구진은 한국이 개발도상국의 건강 증진에 기여할 수 있는 중요한 분야로 소녀들의 건강과 교육을 제시하고자 한다. 소녀가 소녀다운 삶을 살 수 있도록 하는 것이 궁극적으로 그 사회가 건강하고 그 국가가 경제와 사회발전을 이룩하고, 더 나아가서 우리 지구촌이 건강하게 되는 것이다. 한국이 글로벌 보건협력의 장에서 교육을 포함하는 포괄적 소녀건강을 위해서 연구, $\mathrm{ODA}$ 사업 발굴과 집행을 활발히 하여 전 세계 보건의 사각분야인 영유아 사망률 감소 및 모성건 강 증진에 기여할 수 있을 것이다. 


\section{〈참고문헌〉}

김은미·안명옥·오충현·강민아·하은희·신현상. 2014. “국제개발협력과 보건의료" [국제 보건의료재단 역량강화 사업 교재]. 서울: 한국국제보건의료재단 김은미·정혜원·이지은·임세은. 2015. "Young People's Empowerment in Reproductive Health Through Awareness and Service Expansion in Ethiopia (YERASEE) 사 업현장 방문 결과보고서.” 성남: 한국국제협력단 김은실. 2011. “8. 국가와 여성의 출산력.” 『여성의 몸, 몸의 문화정치학』. 서울: 또 하나 의 문화. pp.311-23

문옥륜. 2012. “대한민국 지역보건 60 년의 역사개관." 지역보건 60 년의 발자취』 제 2 권.

서울: 지역보건의료발전을 위한 모임. pp.16-103 박형종·김공현. 1991. “1차 보건의료와 바람직한 정책방향.” 『보건행정학회지』. 1(1): 95-108

방숙. 1986. “우리나라의 가족계획 사반세기.” 양재모 교수 정년퇴임 기념 학술강연집. 서 울: 연세대학교 . 2012. “보건사업 40년의 회고 - 나의 경험을 중심으로." 『지역보건 60년의 발자

취』 제1권. 서울: 지역보건의료발전을 위한 모임. pp.10-41

안명옥. 2014. “여성의 평생건강과 모자보건-생애주기적 관점.” 한국모자보건학회지』. 18(1): $1-12$

통계청. 각년도. 『인구동태통계연보』

$\mathrm{KDI}$ 국제정책대학원. 2011. "경제발전경험 모듈화 사업: 보건소 중심 농어촌 보건의료 개선 사업.” 서울: 보건복지부, 한국국제보건의료재단

Anderson, S. E., Gerard E. D. \& Aviva, M. 2003. "Relative Weight and Race Influence Average Age at Menarche: Results From Two Nationally Representative Surveys of US Girls Studied 25 Years Apart.” Pediatrics 111(4): $844-50$

Asnake, Mengistu, Claire B. Cole, Gwyn Hainsworth, Jill Hodges, Worknesh Kereta, Kidest Lulu, and Callie Simon. 2012. "Bringing Youth-Friendly Services to Scale in Ethiopia.” Addis Ababa: Pathfinder International 
Black, R. E., Allen, L. H., Bhutta, Z. A., Caulfield, L. E., De Onis, M., Ezzati, M., and Maternal and Child Undernutrition Study Group. 2008. "Maternal and Child Undernutrition: Global and Regional Exposures and Health Consequences.” The Lancet 371(9608):243-60

Ernest L. Abel. 1980. "Smoking During Pregnancy: A Review of Effects on Growth And Development of Offspring.” Human Biology 52(4):593-625

EDCF. 2014. "EDCF Statistics Report." Seoul: Economic Development and Cooperation Fund

Fatusi, Adesegun and Michelle J Hindin. 2010. "Adolescents and Youth in Developing Countries: Health and Development Issues in Context." Journal of Adolescence 33(4):499-508

Govender, V., and Penn-Kekana, L. 2008. "Gender Biases and Discrimination: A Review of Health Care Interpersonal Interactions.” Global Public Health 3(S1):90-103

Hainsworth, Gwyn, and Ivone Zilhao. 2009. "From Inception to Large Scale:

The Geracao Biz Programme in Mozambique.” Geneva: World Health Organization Hidalgo, Luis A., Peter A. Chedraui, and Maria J. Chávez. 2005. "Obstetrical and Neonatal Outcome in Young Adolescents of Low Socio-economic Status: A Case Control Study." Archives of Gynecology and Obstetrics 271(3):207-11 Jones, L. L., et al. 2009. "Age at Menarche and the Evidence for a Positive Secular Trend in Urban South Africa." American Journal of Human Biology 21(1):130-2

KOFIH. 2011. "KOFIH $5^{\text {th }}$ Anniversary White Paper 2006-2011.” Seoul: Korea Foundation for International Healthcare

KOICA. 2014. "KOICA Statistics." Seoul: Korea International Cooperation Agency

Kongnyuy, E. Justine, Philip N. Nana, Nelson Fomulu, Shey C. Wiysonge, Luc Kouam and Anderson S. Doh. 2008. "Adverse Perinatal Outcomes of Adolescent Pregnancies in Cameroon." Maternal and Child Health Journal Maternal 12(2):149-54 
MacQuarrie, Kerry. 2014. "Unmet Need for Family Planning among Young Women: Levels and Trends.” Washington D.C.: USAID

Marmot, Friel, Bell, Houweling, T. A., Taylor, S., and Commission on Social Determinants of Health. 2008. "Closing the Gap in a Generation: Health Equity through Action on the Social Determinants of Health." The Lancet 372(9650):1661-9

McGuire, James W. 2010. "South Korea: Small Welfare State, Fast Infant Mortality Decline." in Wealth, Health, and Democracy in East Asia and Latin America. New York: Cambridge University Press

Mesfin, Y. M., Hailemariam, D., Biadglign, S., and Kibret, K. T. 2014. "Association between HIV/AIDS and Multi-Drug Resistance Tuberculosis: A Systematic Review and Meta-Analysis.” PloS one 9(1):e82235

Miriam Temin and Ruth Levine. 2009. "Start with a Girl: A New Agenda for Global Health.” Washington D.C.: Center for Global Development

Nigenda, G., et al. 2003. "Womens' Opinions on Antenatal Care in Developing Countries: Results of a Study in Cuba, Thailand, Saudi Arabia and Argentina.

” BMC Public Health 3(17):1-12

Office of the United Nations High Commissioner for Human Rights. 1989. "Convention on the Rights of the Child." Geneva: Office of the United Nations High Commissioner for Human Rights

Pathfinder. 2015. “Adolescent and Youth Reproductive Health Program Update.” Addis Ababa: Pathfinder International

Pettitt, D. J., Aleck, K. A., Baird, H. R., Carraher, M. J., Bennett, P. H., and Knowler, W. C. 1983. "Excessive Obesity in Offspring of Pima Indian Women with Diabetes during Pregnancy.” New England Journal of Medicine 308(5): 242-5 1988. "Congenital Susceptibility to NIDDM: Role of Intrauterine Environment.” Diabetes 37(5): 622-8

Rizk, D. E., El-Zubeir, M. A., Al-Dhaheri, A. M., Al-Mansouri, F. R., and Al Jenaibi, H. S. 2005. "Determinants of Women's Choice of their Obstetrician and Gynecologist Provider in the UAE." Acta Obstetricia et Gynecologica Scandinavica 84(1): 48-53 
Sawyer, Afifi, Bearinger, Blakemore, Ezeh and Patton, G. C. 2012. Adolescence: a Foundation for Future Health.” The Lancet 379(9826):1630-40

Sommer, M., Carla, S., \& Venkatraman, C. M. 2014. "Putting Menarche and Girls into the Global Population Health Agenda.” Reproductive Health 12(1):24

Tylee, Andre, Dagmar M. Haller, Tanya Graham, Rachel Churchill and Lena A. Sanci. 2007. "Youth-friendly Primary-care Services: How Are We Doing and What More Needs to be Done?." The Lancet 369(9572):1565-73

UN. 2015. “UN Millennium Development Goals Report 2015.” New York: United Nations

UNAIDS, UNDP, UNECA, UNESCO, UNFPA, UNHCHR, UNHCR, UNICEF, UNIFEM and WHO. 2008. "Eliminating Female Genital Mutilation: An Interagency Statement.” Geneva: World Health Organization

UNAIDS and World Health Organization. 2013. "WHO: GLOBAL AIDS RESPONSE PROGRESS REPORTING 2013: Construction of Core indicators for monitoring the 2011 UN Political declaration on HIV/AIDS.” Geneva: World Health Organization Vander Kamp, K. 2004. "High Quality Refugee Education: The Impact of Funding." Education In Emergencies and Post-Conflict Situations 25, available at http://www.tc.columbia.edu/sie/journal/Volume_1/VanderKamp.pdf 2016.03.)

World Health Organization. 2011a. "Closing the Gap: Policy into Practice on Social Determinants of Health: Discussion Paper." Geneva: World Health Organization

2011b. "The Sexual and Reproductive Health of Younger Adolescents in Developing Countries: Research Issues in Developing Countries: Background Paper for Consultation.” Geneva: World Health Organization 2014. "Health for the World's Adolescents. A Second Chance in the Second Decade. A Second Chance in the Second Decade." Geneva: World Health Organization

OECD. 2005. Health Data, 2005

Save the Children. 2015. "Ebola Crisis Appeal" on Save the Children website, available at http://www.savethechildren.org.uk/about-us/emergencies/ebola-crisis（접 속일: 2016.03.) 